\title{
Geomorphological changes in an arid transgressive coastal dune field due to natural processes and human impacts
}

\author{
Antonio I. Hernández-Cordero, ${ }^{1 *}$ (iD) Luis Hernández-Calvento, ${ }^{1}$ Patrick A. Hesp ${ }^{2}$ and Emma Pérez-Chacón ${ }^{1}$ \\ ${ }^{1}$ Grupo de Geografía Física y Medio Ambiente, Instituto de Oceanografía y Cambio Global, IOCAG, Universidad de Las Palmas de \\ Gran Canaria, ULPGC, Parque Científico-Tecnológico de Taliarte, Las Palmas, Spain \\ 2 Beach and Dune Systems (BEADS) Laboratory, College of Science and Engineering, Flinders University, Adelaide, Australia
}

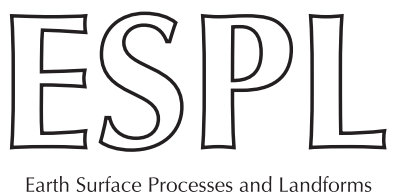

ABSTRACT: Geomorphological changes in recent decades in an arid transgressive coastal dune system (Maspalomas, Gran Canaria, Canary Islands) are analyzed. The methodology used is based on the generation of two geomorphological maps (1961 and 2003) by interpretation of digital orthophotos. The overlay of both maps in a geographic information system (GIS) enabled the spatial and surface changes of the landforms to be determined, and the processes that generated these changes. Twelve cultural and geomorphological processes were identified from highest to lowest importance, namely: anthropization by urban occupation (114 ha changed), stabilization (92.5 ha), barchanization (37 ha), salinization/halophytication (15 ha), anthropization (12.4 ha), deflation (11.8 ha), dune loss/beach gain (11.3 ha), dune formation (9.6 ha), progradation (8 ha), retrogradation (7.7 ha), destabilization (2.7 ha) and flooding (0.7 ha). Geomorphological changes are associated with a combination of five main factors, three of anthropogenic origin and two natural ones. The natural factors are: (1) the arid climate, which favors changes occurring at high speed; (2) the existence of a progressive sedimentary deficit. Anthropogenic factors are: (3) construction of tourist urbanizations, infrastructures and facilities; (4) installation of equipment or infrastructure on the beaches; (5) the activities carried out by users. These human factors have altered the aeolian dynamics and reduced the area occupied by vegetation in some areas, causing changes in aeolian sedimentary processes. The geomorphological processes identified can be used as indicators of environmental change, allowing us to synthesize the changes in landforms detected, and group all combinations derived from the analysis by GIS and analyze them spatially. Thus, the environmental changes in the transgressive coastal dune systems could be interpreted more effectively. Copyright @ 2018 John Wiley \& Sons, Ltd.

KEYWORDS: aeolian sedimentary landforms; geomorphological and environmental changes; geoindicator; spatio-temporal dynamics; urban-tourist impacts

\section{Introduction}

Transgressive dune sheets and dune fields commonly comprise three main types: sand sheets, nebkha fields and dune fields (Hesp and Walker, 2013). They consist mainly of simple sheets (generally lacking dune forms), dunefields with free dunes such as barchan dunes, barchanoid ridges, transverse dunes, etc., and also other landforms such as blowouts, slacks or deflation areas, nebkhas (dunes formed by sand deposition within discrete plants), remnant knobs, etc. (Hesp and Walker, 2013). Transgressive systems are very dynamic, showing significant changes in short periods. This is related to the high mobility of the dunes as compared to vegetated systems (Hesp, 1991; Rust and Illenberger, 1996). However, transgressive dune systems have variable rates of dune movement, depending on different environmental factors (climatic characteristics, vegetation cover, sand volume, progradation rates, etc.). The transgressive systems in arid regions tend to be more highly dynamic due to the minor role played by the vegetation, and by the limitations imposed by scarce and irregular rainfall (Cabrera-Vega et al., 2013; Hesp, 2013; Jackson et al., 2013; HernándezCordero et al., 2015).

Geomorphological changes that occur within transgressive dune systems are associated with both natural causes, especially related to changes in climatic characteristics (Martinho et al., 2010; Levin, 2011; Miot da Silva et al., 2013; Miot da Silva and Hesp, 2013), and also to human actions (Alonso et al., 2002; Granados Corona et al., 1988; Hesp, 2001; Tsoar and Blumberg, 2002; Kutiel et al., 2004; Levin and Ben-Dor, 2004; Mitasova et al., 2005; Carretero et al., 2014), or a combination of both (Piotrowska, 1989; Marcomini and Maidana, 2004; Pye et al., 2014).

Geomorphological changes in coastal dune fields produced by human activities are due to (1) building structures, (2) extracting resources, (3) walking or driving on these systems, (4) modifying the surface to accommodate recreational facilities, (5) redistributing sediments or removing sediments 
(mining, etc.), (6) planting vegetation to increase the level of protection or stabilize naturally mobile dunes, and (7) altering the surface to remobilize stabilized landscapes (Jackson and Nordstrom, 2011).

In the case of Maspalomas, the environmental changes experienced are related to the progressive stabilization of the inland dunes; the expansion of the areas occupied by deflation surfaces; lowering the height of the dunes; an increase of the distance of the first free dunes with respect to the beach; the widespread increase in vegetation cover; the fragmentation of the foredune and the decline in populations of Traganum moquinii the dominant pioneer plant species (Hernández-

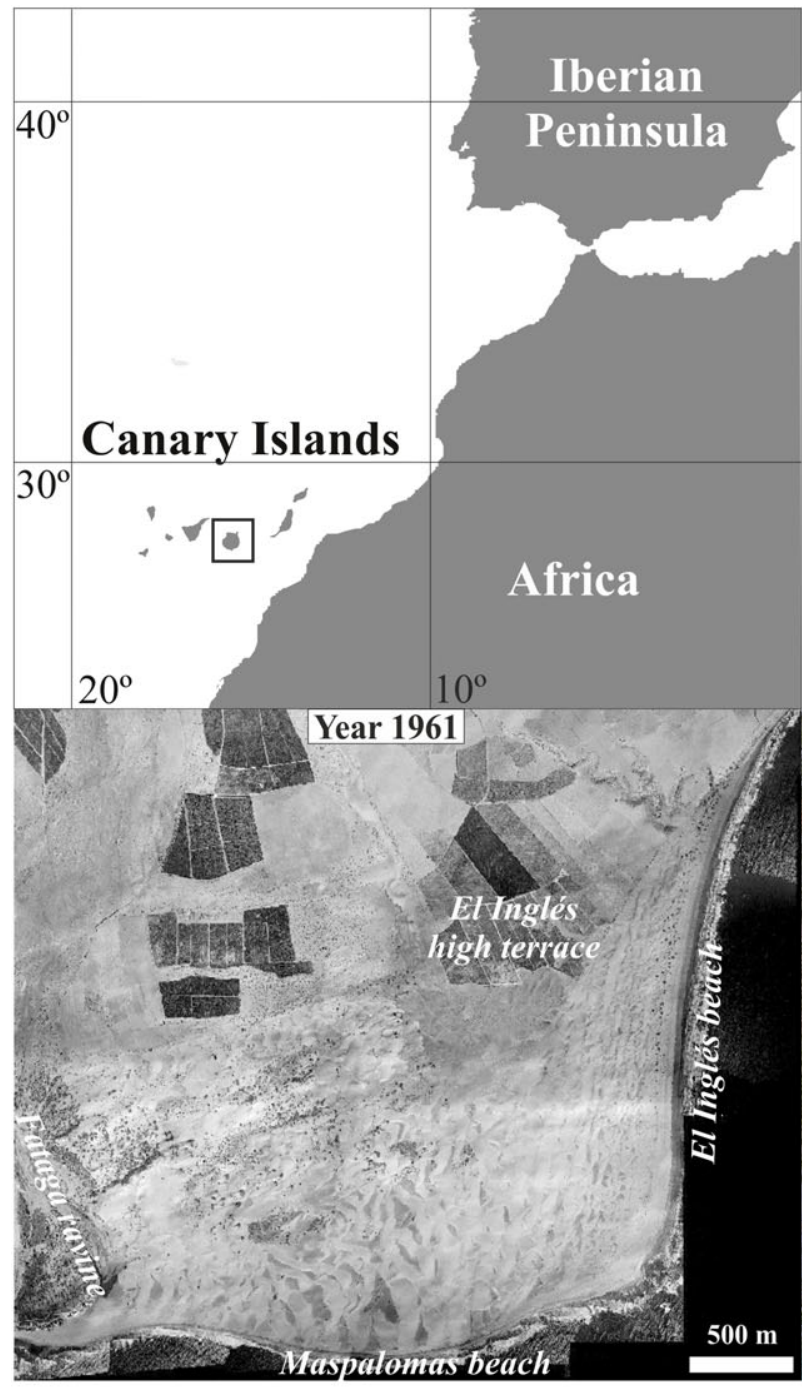

Frequency of wind directions in Maspalomas (November 1997-April 2011)

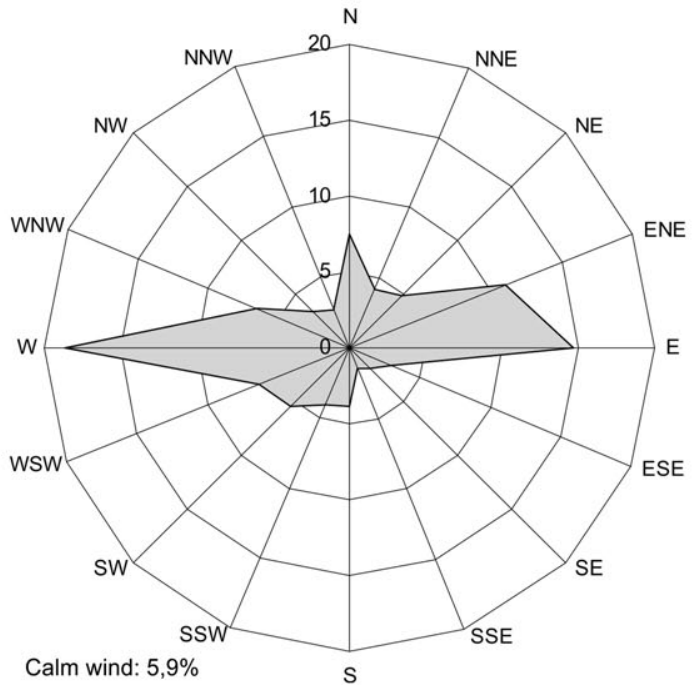

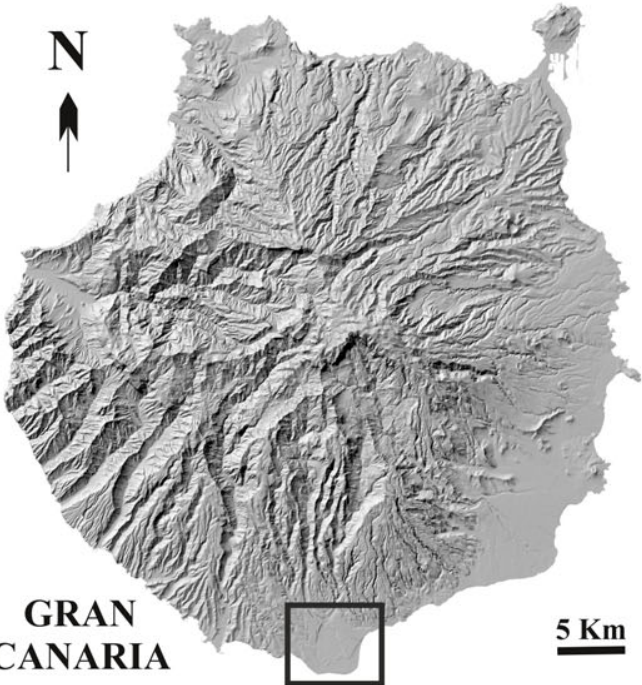

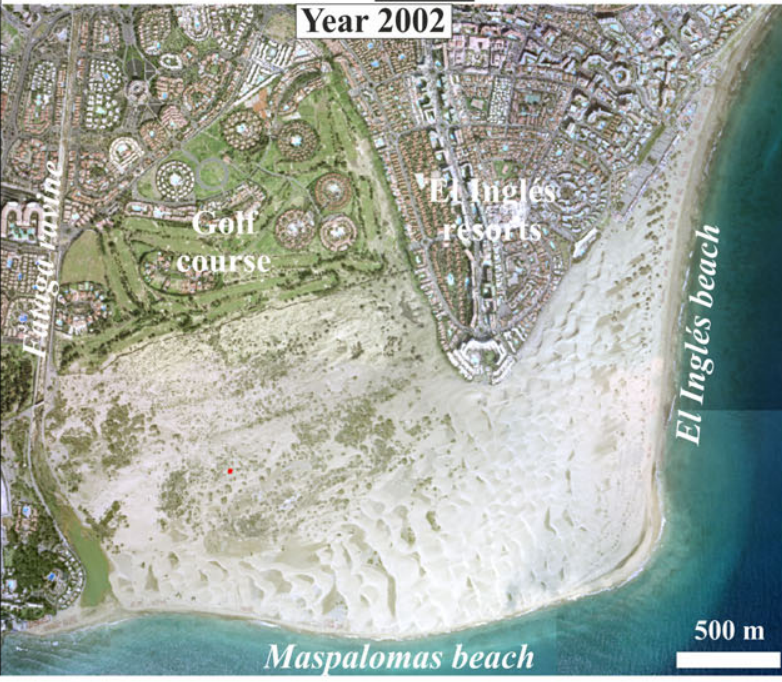

Frequency of effective winds directions (November 1997-April 2011)

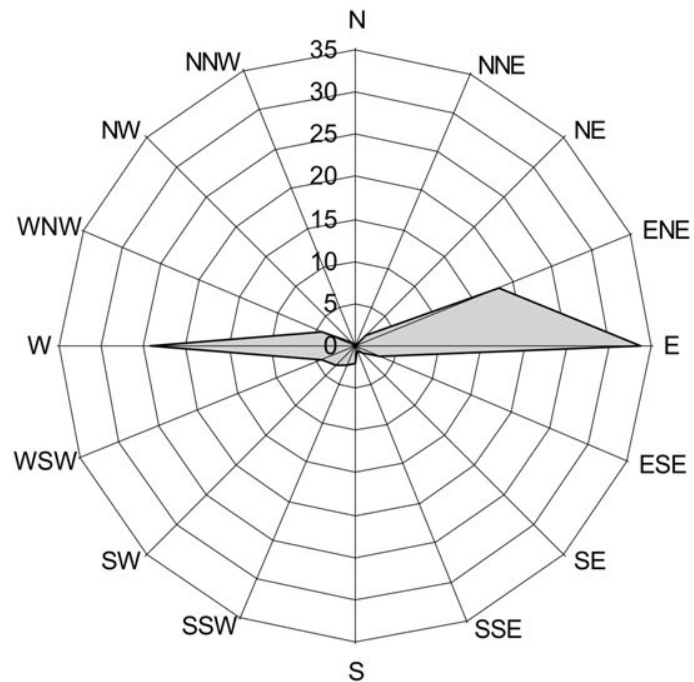

Figure 1. Location of the Maspalomas dune system and its features before (1961) and after (2002) tourist development. Source of the orthophotos: IDECanarias (GRAFCAN, S.A.). Wind roses: frequency of wind direction (left) and frequency of effective winds (> $5 \mathrm{~m} / \mathrm{s})$ direction (right) (modified from Máyer Suárez et al., 2012). [Colour figure can be viewed at wileyonlinelibrary.com] 
Calvento, 2006; Hernández et al., 2007; Hernández-Cordero et al., 2012). These environmental changes are associated with tourist development which started in the 1960s and which has altered the aeolian sedimentary dynamics, as well as a natural sedimentary deficit (Hernández-Calvento et al., 2014).

This paper aims to analyze the geomorphological changes experienced in the dune system of Maspalomas (Gran Canaria, Canary Islands, Spain) between 1961, before the start of tourist activity, and 2003, through the identification and characterization of geomorphic processes, as indicators of the environmental changes.

\section{Study Area}

Maspalomas is an arid transgressive coastal dune system located in the south of the island of Gran Canaria (Canary Islands, Spain) (Figure 1). At the western boundary of the dune system there is a lagoon located in the mouth of Fataga ravine ('Charca de Maspalomas' or 'Maspalomas Pond'), adjacent to a portion of the mobile dune system. This ravine was modified by the diversion of its riverbed and partial channeling. The average annual rainfall is $81 \mathrm{~mm}$ (period 1952-2008) with large annual and interannual variability, and an average annual temperature of $21^{\circ} \mathrm{C}$ (1997-2007) (Hernández-Cordero et al., 2015). Sand input to the system is from the east coast (EI Inglés beach), where free dunes (barchan dunes and barchanoid ridges) are formed that advance due the trade winds to the south coast (Maspalomas beach). The winds present a balance between two opposing directions (east-northeast and west), but a clear dominance of the east and northeast directions when effective winds are in operation (winds $>5 \mathrm{~m} / \mathrm{s}$ that can move the sand) (Máyer Suárez et al., 2012; Figure 1). For this reason, the dunes move from northeast to southwest. Aeolian dynamics have been altered due to tourism development (Hernández-Calvento et al., 2014; Smith et al., 2017). The buildings built on the adjacent El Inglés high terrace, a sedimentary terrace that is above the dunefield, increased the wind speed notably, and values increased between 30 and 35\% in the area close to the southern end of the terrace. A wide shadow zone at the leeward margin of the terrace can be also observed with decreases of up to $50 \%$ in wind speed.

The general coastal drift transports the sediments from El Inglés beach (east coast) to the Maspalomas beach (south coast). However, when there are storms from the southwest, the Maspalomas beach is eroded and the sediments are transported towards the $\mathrm{EI}$ Inglés beach (Hernández-Calvento, 2006). The mean tidal range in the Canary Islands is between 1 to $2.5 \mathrm{~m}$.

\section{Methodology}

The methodology is based on an analysis of the geomorphological changes using geographic information systems (GIS). Two vector layers of landforms were created for the years 1961, before the tourist development, and 2003 following significant tourist development. Two digital orthophotos were interpreted, and the landforms were identified and digitized. The orthophoto from 1961 has a spatial resolution of $12.5 \mathrm{~cm} /$ pixel and it was obtained from the spatial data infrastructure of Canary Islands (IDECanarias, GRAFCAN, S.A., Gobierno de Canarias). The orthophoto of 2003 has a spatial resolution of $15 \mathrm{~cm} /$ pixel and belongs to the research group Geografía Física y Medio Ambiente of the University of Las Palmas de Gran Canaria. To avoid any confusion between seasonal and temporary changes, a very important issue in the intertidal zone, the area of contact between the dry and wet sand was used as the lower limit of the beach, because it remains relatively stable. The two layers generated were overlaid in the GIS, resulting in a derived layer containing the spatiotemporal geomorphological changes. The changes were categorized into specific process groups, as a tool to better understand the complex changes. In turn, geomorphological processes indicate the evolutionary trends of the system based on both natural and human factors.

\section{Results}

\section{Geomorphological characteristics in 1961}

In the 1960s before the beginning of tourist development, the dune system covered an area of 474.9 ha. Free sheets and dunes predominated in Maspalomas, as sand sheets, barchan dunes, and barchanoid ridges, that together covered $69.2 \%$ of the surface of the dune system (Table I; Figure 2).

The system consisted of a sandy beach (El Inglés beach), where sediments entered into the system, and a foredune zone formed by nebkhas (Hernández-Cordero et al., 2012; Hernández-Calvento et al., 2014). The barchanoid ridges were located landwards of the foredune, where barchan dunes and sand sheets also occurred. A portion of these dunes migrate across to the Maspalomas beach and go out to the sea by that beach. Other free dunes were located to leeward of the El Inglés high terrace. To occur in these zones the dunes had to climb up and fall down this terrace [ $25 \mathrm{~m}$ above sea level (a.s.I.)] in the form of climbing dunes and cliff-top dunes (HernándezCalvento, 2006; Figure 2). Barchan dunes and sand sheets were located behind the barchanoid ridges. The remaining landforms were variously dispersed across the study area.

\section{Geomorphological characteristics in 2003}

In 2003 the surface of the Maspalomas dune system was reduced to $360.9 \mathrm{ha}$, because a part of the historic dune field was occupied by tourist urbanization, infrastructures and facilities. The dominant landforms are barchanoid ridges, stabilized dunes and barchan dunes and sand sheets (Table II). It also highlights the area occupied by the beaches, deflation surfaces and nebkhas.

In 2003 both the area occupied by the landforms and also their spatial distribution have changed substantially as compared to 1961 (Figure 3). Thus, the foredune reduced its total surface area and it has been fragmented. Landwards the barchanoid ridges have been replaced by barchan dunes, sand sheets and deflation surfaces (Hernández-Calvento, 2006;

Table I. Surface covered by the beach and aeolian landforms in 1961

\begin{tabular}{lcr}
\hline Landform & Surface (ha) & $\%$ \\
\hline Barchanoid ridges & 225.3 & 47.4 \\
Barchan dunes and sand sheets & 103.6 & 21.8 \\
Nebkhas & 44.7 & 9.4 \\
Stabilized dunes & 21.6 & 4.5 \\
Beach & 18.5 & 3.9 \\
Cliff-top dunes & 14.1 & 3.0 \\
Foredune & 13.2 & 2.8 \\
Deflation surfaces & 10.1 & 2.1 \\
Echo dunes & 8.4 & 1.8 \\
Falling dunes & 6.7 & 1.4 \\
Sand mining & 5.3 & 1.1 \\
Climbing dunes & 3.3 & 0.7 \\
Total & 474.9 & 100.0 \\
\hline
\end{tabular}




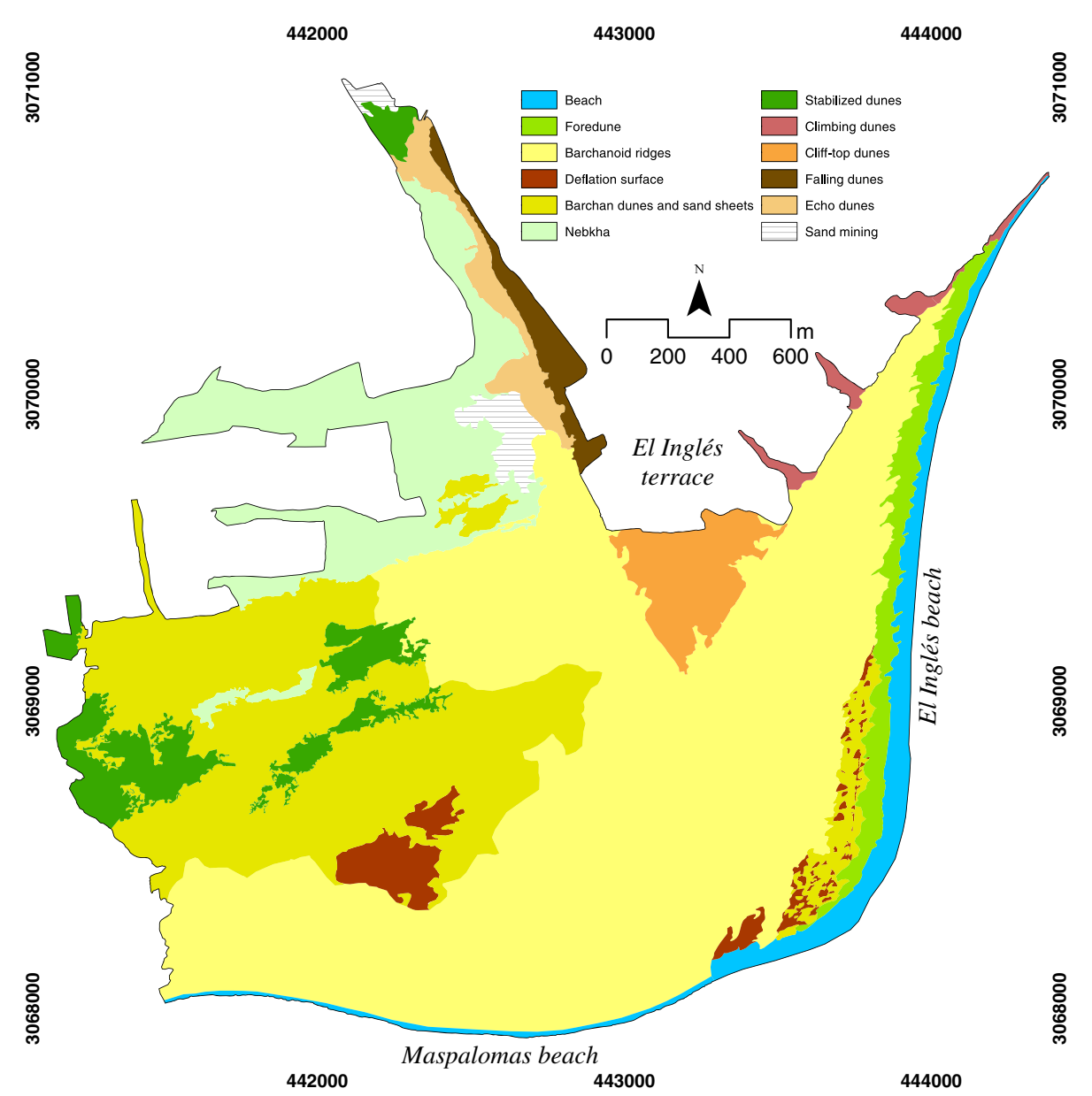

Figure 2. Map of landforms in 1961. [Colour figure can be viewed at wileyonlinelibrary.com]

Table II. Surface covered by beach, aeolian and anthropogenically influenced landforms in 2003

\begin{tabular}{lcr}
\hline Landform & Surface (ha) & $\%$ \\
\hline Barchanoid ridges & 115.1 & 31.9 \\
Stabilized dunes & 90.9 & 25.2 \\
Barchan dunes and sand sheets & 56.1 & 15.5 \\
Beach & 32.3 & 8.9 \\
Deflation surfaces & 32.2 & 8.9 \\
Nebkhas & 11.8 & 3.3 \\
Foredune & 9.5 & 2.6 \\
Anthropogenic deposits & 5.4 & 1.5 \\
Sand mining & 3.2 & 0.9 \\
Anthropogenic deposits with sand & 2.7 & 0.7 \\
Slope with anthropogenic deposits & 1.7 & 0.5 \\
Total & 360.9 & 100.0 \\
\hline
\end{tabular}

Hernández et al., 2007; Hernández-Cordero et al., 2012; Hernández-Calvento et al., 2014). The deflation surfaces and Nebkhas now occupy much of the central area of the system, while the stabilized dunes cover all the area to leeward of El Inglés high terrace (Figure 3).

\section{Landforms changes between 1961 and 2003: geomorphological processes}

Most of the area occupied by the dune system in 1961 (66.4\%) has changed by 2003, while $33.6 \%$ currently contains the same landforms existing in the 1960s (Table III). Note however, that due to the transgressive nature of the dunes and the progradation of the coast, in some areas the dune field has transgressed the limits occupied in 1961 (Table III; Figure 4).

Unchanged areas are associated with barchanoid ridges (108.2 ha; $67.1 \%)$, barchan dunes and sand sheets (14.4 ha; $8.9 \%$ ), beach (13 ha; $8.1 \%)$, stabilized dunes (11.2 ha; $6.9 \%$ ), foredune (7.2 ha, $4.5 \%$ ) and deflation surfaces (5.6 ha, 3.5\%).

Changes in landforms detected between 1961 and 2003 were grouped into 12 process categories (Figure 4; Table III), namely: anthropization by urban occupation, stabilization, barchanization, salinization/halophytication, anthropization, deflation, dune loss/beach gaining, dune formation, progradation, retrogradation, destabilization and flooding.

Anthropization by urban occupation

This process occupies 114.5 ha of the study region. It is due to the construction of urbanization, infrastructure and facilities associated with tourism (buildings, golf courses, shopping centers, roads, etc.) over dunes of different types. Therefore, it is a process that has resulted in the disappearance of part of Maspalomas dune field, significantly reducing its surface area, dune types and various aeolian processes. This has mainly occurred in the northern area of the dune field that existed in 1961.

\section{Stabilization}

The stabilization area is $92.5 \mathrm{ha}$. This process involves the transformation of free dunes into vegetated dunes, either stabilized dunes (Figure 5) or landforms that still have active aeolian sedimentary processes, such as foredunes or nebkhas (Figure 6). The transformation of Nebkhas into stabilized dunes 


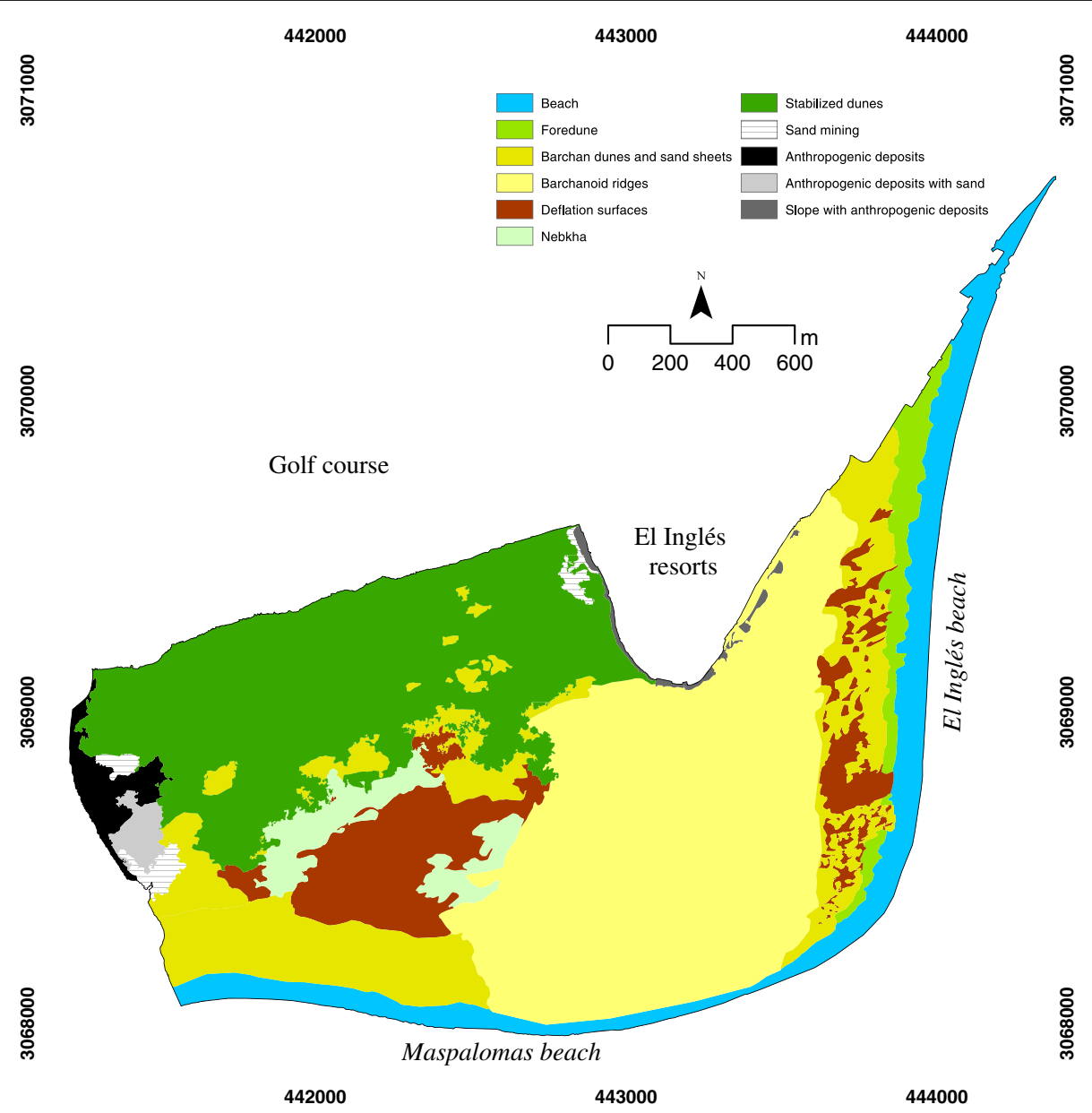

Figure 3. Map of landforms in 2003. [Colour figure can be viewed at wileyonlinelibrary.com]

Table III. Geomorphological and cultural processes identified in the Maspalomas dune system related to landforms changes between 1961 and 2003

\begin{tabular}{lcr}
\hline Geomorphic and cultural process & Surface (ha) & $\%$ \\
\hline No changes & 159.6 & 33.6 \\
Anthropization by urban occupation & 114.5 & 24.1 \\
Stabilization & 92.5 & 19.5 \\
Barchanization & 37.3 & 7.9 \\
Salinization/halophytication & 14.9 & 3.1 \\
Anthropization & 12.4 & 2.6 \\
Deflation & 11.8 & 2.5 \\
Dune loss/beach gaining & 11.3 & 2.4 \\
Dune formation & 9.6 & 2.0 \\
Retrogradation & 7.7 & 1.6 \\
Destabilization & 2.7 & 0.6 \\
Flooding & 0.7 & 0.1 \\
Total & 474.9 & 100 \\
Processes that have exceeded the & & \\
$\quad$ limits of the dune system in 1961 & & - \\
Dune formation & 0.2 & - \\
Progradation & 7.9 & \\
\hline
\end{tabular}

is also included in this process, since we believe that in arid transgressive coastal dunes systems, the Nebkhas are a transition form to the stabilized dunes (see e.g. Hesp, 2013), and involves a reduction of the aeolian sedimentary processes.

Most of the surface changes due to this process consists of transforming barchan dunes and sand sheets to stabilized dunes, followed by barchanoid ridges to stabilized dunes and also from barchan dunes and sand sheets to nebkhas
(Figure 7). This process has occurred mainly in the lee of El Inglés high terrace.

\section{Barchanization}

The area changed due to barchanization has a surface of $37.3 \mathrm{ha}$. It is a dune simplification process, i.e. a decrease in the complexity of the free dunes. It is the transformation of barchanoid ridges into barchan dunes and sand sheets (Figure 8). This process has occurred mainly at both the eastern and western limits of the dune system, i.e. in the sediment input and output areas. In the input area the barchanization extends behind the foredune, whereas in the output zone it has affected the last mobile dunes (southwest of the system).

\section{Salinization/halophytication}

The area due to the salinization process occupies $14.9 \mathrm{ha}$. It is constituted, in turn, by two other processes: first, deflation of the dunes, and, second, the subsequent colonization of deflation surfaces by plants. This plant colonization is mainly driven by halophilous species, such as Suaeda mollis and Tetraena fontanesii, as well as hygrophilous species, such as Juncus acutus and Tamarix canariensis (Hernández-Cordero et al., 2006). Landform changes in this process are from barchanoid ridges to deflation surfaces with halophytic vegetation, and from barchan dunes and sand sheets to deflation surfaces with halophytic vegetation (Figure 9). This process also includes areas where landforms have not changed during the study period, but the colonization of deflation surfaces by plants has occurred in places not occupied by vegetation in 1961 . The salinization/halophytication has mainly occurred in the central part of the dune system. 


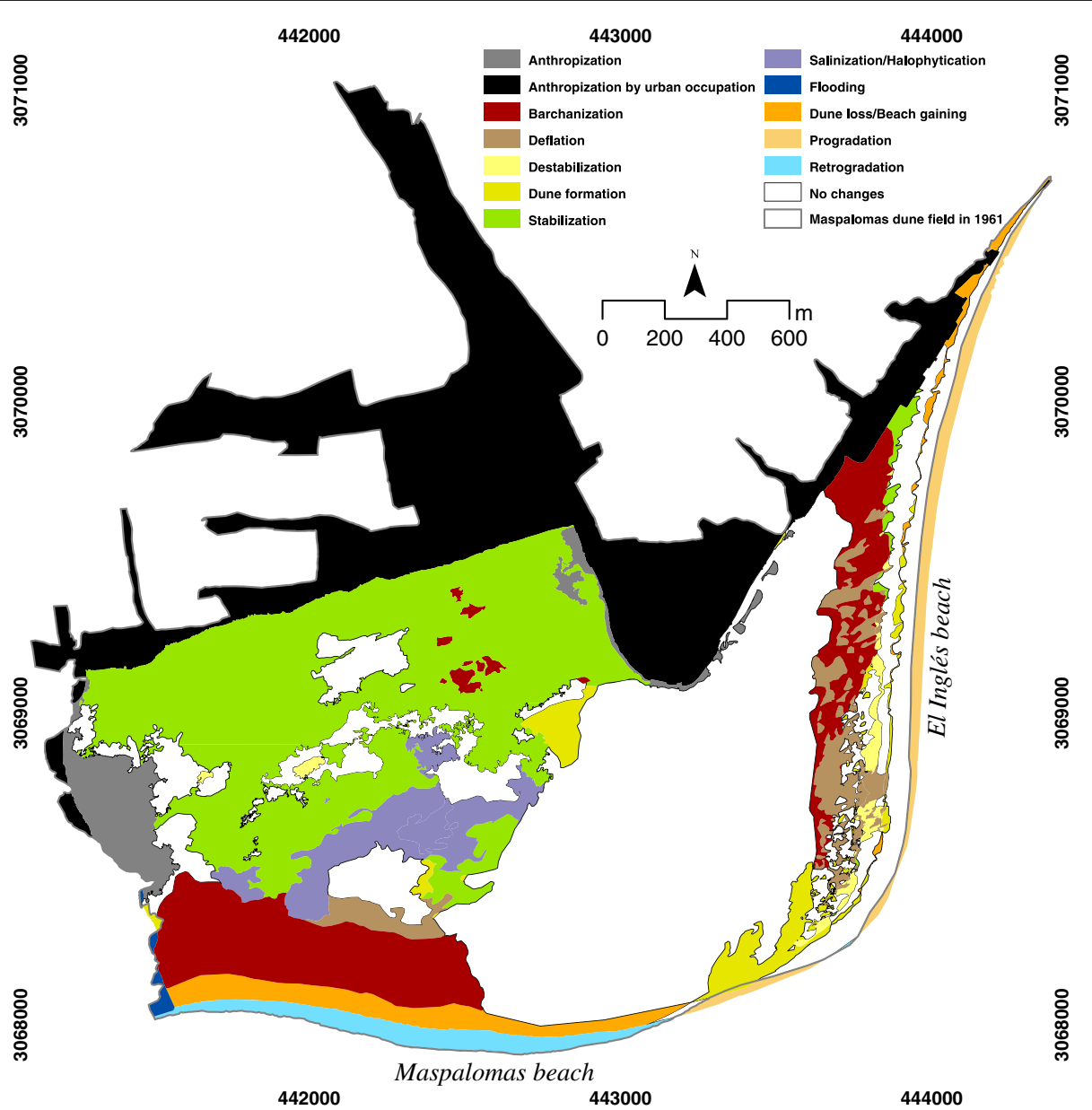

Figure 4. Map of geomorphological process categories or groups identified in the Maspalomas dune system between 1961 and 2003 . [Colour figure can be viewed at wileyonlinelibrary.com]

\section{Anthropization}

The surface area changes due to anthropization is 12.4 ha. Dune landforms are modified by direct human action, as a result of works produced during the early stages of tourist development, forming anthropogenic deposits composed by built infrastructure, debris, removed material, etc.

The most significant landform changes associated with this process are stabilized dunes to anthropogenic deposits, from barchan dunes and sand sheets to anthropogenic deposits with sand, and from barchanoid ridges to slopes with anthropogenic deposits (Figure 10). Anthropization has occurred in the eastern and western margins of the current dune system.

\section{Deflation}

Changes in the region due to deflation cover an area of $11.8 \mathrm{ha}$ It is characterized by the formation of deflation surfaces. Unlike salinization/halophytication, this process does not involve plant colonization (Figure 9). This process involves different changes of landforms (Figure 11), among which the transformation of free dunes and sheets (barchanoid ridges, barchan dunes and sand sheets) in erosive landforms is highlighted. It is located in two zones: in the sediment input area and in the center of the system. In the first case, it is due to the replacement of the foredune by deflation surfaces, besides replacing barchan dunes and sand sheets and barchanoid ridges by these erosive landforms. In the central area of the system the change has been from barchanoid ridges.

Dune loss/beach gain/progradation

This process has an area of $11.3 \mathrm{ha}$. It involves the transformation of dune landforms on beaches, in the case of free dunes, and the disappearance of plant species that form the foredune, with the consequent transformation of this landform.

Most of the dune loss/beach gain has been produced by the transformation of barchanoid ridges into beach (Figure 12). This has occurred in the southern part of the system (Maspalomas beach). The transformation of the foredune occurred on EI Inglés beach.

\section{Dune formation}

Dune formation affects 9.6 ha of the region indicating new dune areas created post-1961. Hence, 0.2 ha must be added as the result of progress in the dunes to the west of the historic dune field, occupying areas that were wetlands in the 1960s. This process is associated with two main types of geomorphological changes: on the one hand, the transformation of erosive landforms, as deflation surfaces, or beaches in free or vegetated dunes (foredune or nebkhas); and, on the other hand, it is associated with an increase of the complexity in the existing free dunes, because of a higher sediment input.

Figure 13 shows that most of the dune formation process is associated with the transformation of barchan dunes and sand sheets into barchanoid ridges, deflation surfaces into barchanoid ridges and from beach to barchanoid ridges. The dune formation has occurred mainly in the southern part of El Inglés beach, and also in inner areas.

Progradation

This process involves the seawards progradation of the beach. It occurred at El Inglés beach and it occupies an area of 7.9 ha. 

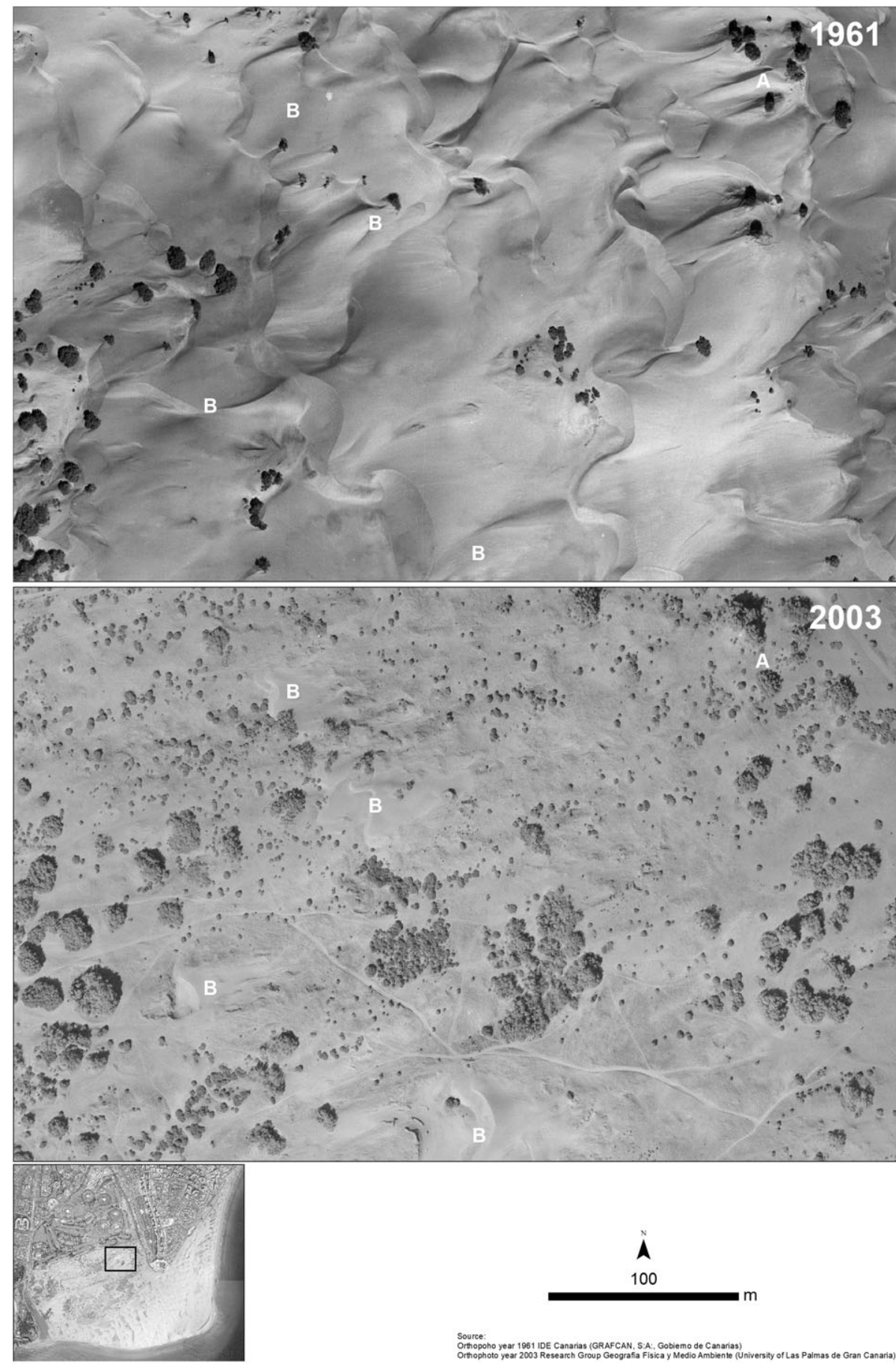

Figure 5. Example of stabilization processes: transformation of free dunes into stabilized dunes between year 1961 (top) and year 2003 (bottom). The letter A indicates the position of a group of trees to facilitate the interpretation of the orthophoto. As can be seen, in 1961, barchanoid ridges predominated, while the vegetation cover was very scarce and was formed mainly by some dispersed tree (specimens of Tamarix canariensis). In 2003 the vegetation cover occupies most of this area, so that the fronts of the dunes can no longer be differentiated due to absence of active aeolian sedimentary processes. The only zones with active aeolian sedimentary processes (B) correspond to the process of barchanization.

\section{Retrogradation}

This process has occurred along Maspalomas beach. It implies a reduction of the surface of the dune system which has been calculated at $7.7 \mathrm{ha}$. The retrogadation has led to the disappearance of beach (2.4 ha) and barchanoid ridges (5.3 ha), with an average coastline recession on the beach of Maspalomas of $37.4 \mathrm{~m}$, and a maximum value of $72 \mathrm{~m}$.

\section{Destabilization}

The process of destabilization occupies an area of $2.7 \mathrm{ha}$. It is the transformation of vegetated dunes into free dunes. The two main changes of landforms that make up this process are: foredune to barchan dunes and sand sheets (2.3 ha), and barchan dunes and sand sheets to stabilized dunes (0.4). The destabilization has occurred mainly in the El Inglés backshore region.

\section{Flooding}

Flooding is a process that occupies 0.7 ha and involves the substitution of the dune landforms, such as barchanoid ridges, by a coastal lagoon (Charca de Maspalomas or Maspalomas pound). This has occurred on the western boundary of the dune system. 


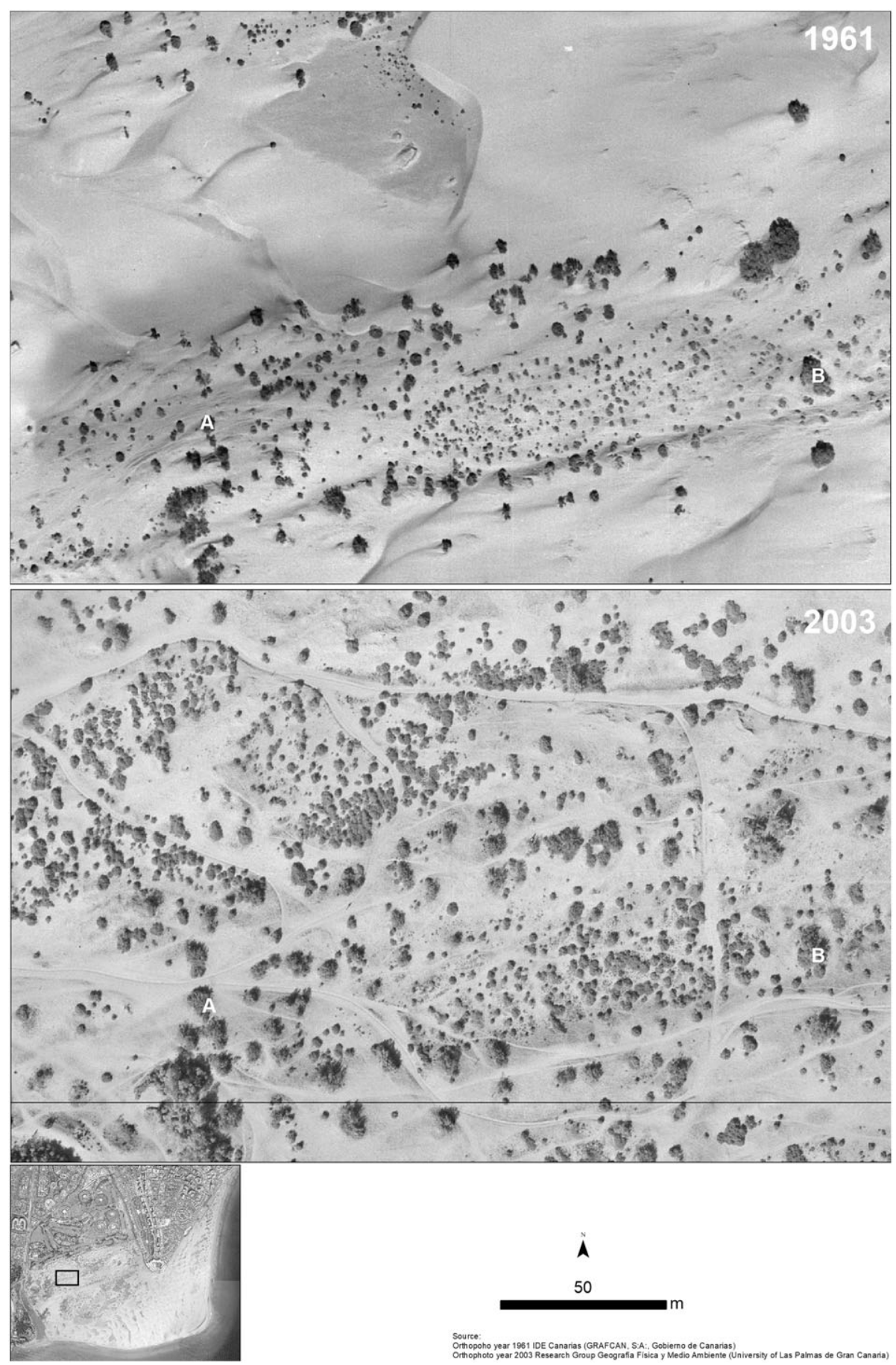

Figure 6. Example of stabilization processes: transformation of nebkhas in stabilized dunes between year 1961 (top) and year 2003 (bottom). Between zones A and B are located nebkhas in 1961 (it is possible to see aeolian sedimentary processes like shadow dunes associate to the nebkhas) and in 2003 they are stabilized dunes, since no aeolian sedimentary processes are appreciated.

\section{Discussion}

Geomorphological changes experienced across the Maspalomas dune system have been previously studied (Hernández-Calvento, 2006; Hernández et al., 2007; CabreraVega et al., 2013; Hernández-Calvento et al., 2014; GarcíaRomero et al., 2016; Smith et al., 2017). In all these studies the effects of tourist development in the transformation process and a decrease in sediment inputs from natural causes are indicated. This paper analyzes the geomorphological changes from a new approach, identifying and characterizing the geomorphological processes that group the spatio-temporal and surface changes of the landforms and that mark certain evolutionary trends. The spatial distribution of processes allows us to analyze the zones that present greatest changes, and the characteristics of these changes (anthropization, erosion, etc.). Therefore, the processes are indicators of geomorphological changes, allowing us to synthesize them, grouping all combinations of landform changes derived from GIS analysis, and analyze them spatially. Thus, it is possible to better interpret the environmental changes in transgressive coastal dune systems. For example, in stabilized dunes in Hungary the historical human impact and its intensity has been determined by studying the geomorphological changes, through morphometric analysis (Kiss et al., 2009).

A part of the Maspalomas dune system remained unchanged between 1961 and 2003. Much of the area unchanged corresponds to an area dominated by barchanoid ridges. This is 


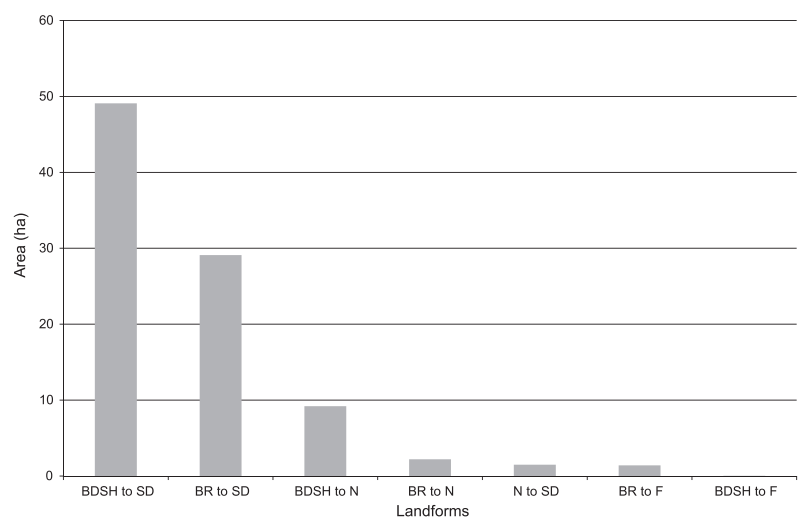

Figure 7. Surface occupied by landform changes due to the stabilization process. BDSH: barchan dunes and sand sheets; SD: stabilized dunes; BR: barchanoid ridges; N: nebkhas; F: foredune.

because these landforms take hundreds of years to make the full journey across the dune system (Ojeda et al., 2007). Therefore, this area is essentially unchanged due to being associated with dune ridges that are currently moving through the dune field. However, $66.4 \%$ of the system of dunes changed their landforms, which have been grouped into 12 processes ordered according to their surface area: anthropization by urban occupation, stabilization, barchanization, salinization/ halophytication, anthropization, deflation, dune loss/beach gaining, dune formation, progradation, retrogradation, destabilization and flooding.

A recent study determined that there is no relationship between the evolution of climatic variables (rainfall and wind) and geomorphological changes in the Maspalomas dune field (Smith et al., 2017). Thus, it appears that the geomorphological changes experienced by the Maspalomas dune system are due to the combination of a progressive natural sedimentary deficit, the construction of tourist urbanizations and infrastructures, the installation of facilities on the beaches and the activities of the tourists (cf. Hernández-Calvento, 2006; Hernández et al., 2007; Hernández-Cordero et al., 2012; Hernández-Calvento et al., 2014). To this must be added the arid climate that favors rapid system changes (Cabrera-Vega et al., 2013).

Geomorphological processes identified in the Maspalomas dune system are associated with different natural and human factors or a combination of them. The processes associated directly to human activity are anthropization by urban occupation and forming anthropogenic deposits (anthropization), which have led to the reduction and modification of the dune system by the construction of tourist urbanization, infrastructures and facilities.

Processes apparently linked to natural factors are dune formation and progradation. The dune formation is primarily associated with the advance of the dunes, which in their migration occupy other landform units such as the deflation surfaces. Meanwhile, the progradation is a process associated with a sedimentary cycle in the Maspalomas dune system, where a part of the sand returns to the beach input area (EI Inglés beach) due to the operation of southwest storms (Hernández-Calvento, 2006). However, the increase in the rate of sediment transport due to tourist urbanizations, with the consequent increase in the amount of sediment that returns back to sea, could explain the progradation at El Inglés beach (Hernández-Calvento et al., 2014).

The remaining processes are a combination of natural factors and human activities arising from tourist development. Three processes, deflation, salinization/halophytication and stabilization are linked indirectly to the urbanization of the high terrace of El Inglés, which produced changes in the aeolian dynamics
(Hernández-Calvento, 2006; Hernández-Calvento et al., 2014; Smith et al., 2017).

Deflation involves forming wind eroded surfaces and this occurred in areas where the wind has been accelerated and also by a natural decline in the contribution of sand input. This process is also related to the disappearance of Traganum moquinii nebkhas, which resulted in the greater fragmentation of the foredune (Hernández-Cordero et al., 2012). Thus, the removal of vegetation in some areas of the backshore produced a replacement of the foredune by deflation surfaces, once the sand trapping plants were eliminated (Hernández-Cordero et al., 2012). The fragmentation of the foredune in combination with altering the wind dynamics by tourist urbanizations could be the cause of the formation of deflation surfaces also in the lee of the foredune zone (Hernández et al., 2007; HernándezCordero et al., 2012; Hernández-Calvento et al., 2014). This is because all these processes have been accelerating the rate of sediment transport, with a consequent increase in the distance between the beach and the first line of mobile dunes (Hernández-Calvento et al., 2014).

The salinization/halophytication process, in addition to forming deflation surfaces, involves the colonization of halophilous plants, such as Suaeda mollis or Tetraena fontanesii, due to the existence of brackish water near the surface (Hernández-Cordero et al., 2006).

Stabilization is the result of a decreased aeolian sediment transport, which favored the plant colonization of the dunes in the wind shadow area to leeward of tourist urbanizations built on the high terrace of El Inglés (Hernández-Calvento et al., 2014).

In recent decades there have been processes of deflation and stabilization in different transgressive dune systems throughout the world, associated with changes in weather conditions (Martinho et al., 2010; Levin, 2011; Miot da Silva et al., 2013; Miot da Silva and Hesp, 2013). In this sense, and considering that the wind is one of the main factors controlling the development of vegetation and therefore the dynamics of transgressive dunes (Tsoar, 2005), some studies indicate that stabilization processes and dune mobility are associated with a decrease or increase in wind speed (Yizhaq et al., 2007; Tsoar et al., 2009). However, other variables such as rainfall and human activities such as grazing, are important in determining the existence of mobile or stabilized dunes (Tsoar and Blumberg, 2002; Kutiel et al., 2004; Levin and Ben-Dor, 2004; Yizhaq et al., 2009), and in some cases both (wind and rainfall; e.g. Miot da Silva et al., 2013). Some recent studies find that the sand transport rate is not dependent on rainfall, arguing that the wind is the main factor that allows the maintenance of transgressive dunes (Yizhaq et al., 2013). This is because the intense winds can dry the sand and, therefore, continue transporting the sediments. Levin (2011) relates changes in the dunes of Fraser Island (Australia) to an increase in wind strength associated with changes in the intensity and frequency of cyclones. Meanwhile, the process of halophytication has been identified in Turkey as the result of an increase in irrigated agricultural land and the consequent soil salinization (Atamov et al., 2006). However, in this case there has not been a geomorphological change but only a biotic one, and it is not associated with any dune systems.

The barchanization occurring in the Maspalomas dune system is a process that seems to be associated with a natural sedimentary deficit. Thus, the reduced availability of sediment has led to a reduction in the complexity of free dune landforms. The barchanization may be part of the morphological cycle of the dunes (Aufrère, 1931), since the difference between barchan dunes and barchanoid ridges is primarily related to the amount of sand available for aeolian transport (Tsoar, 2001; 


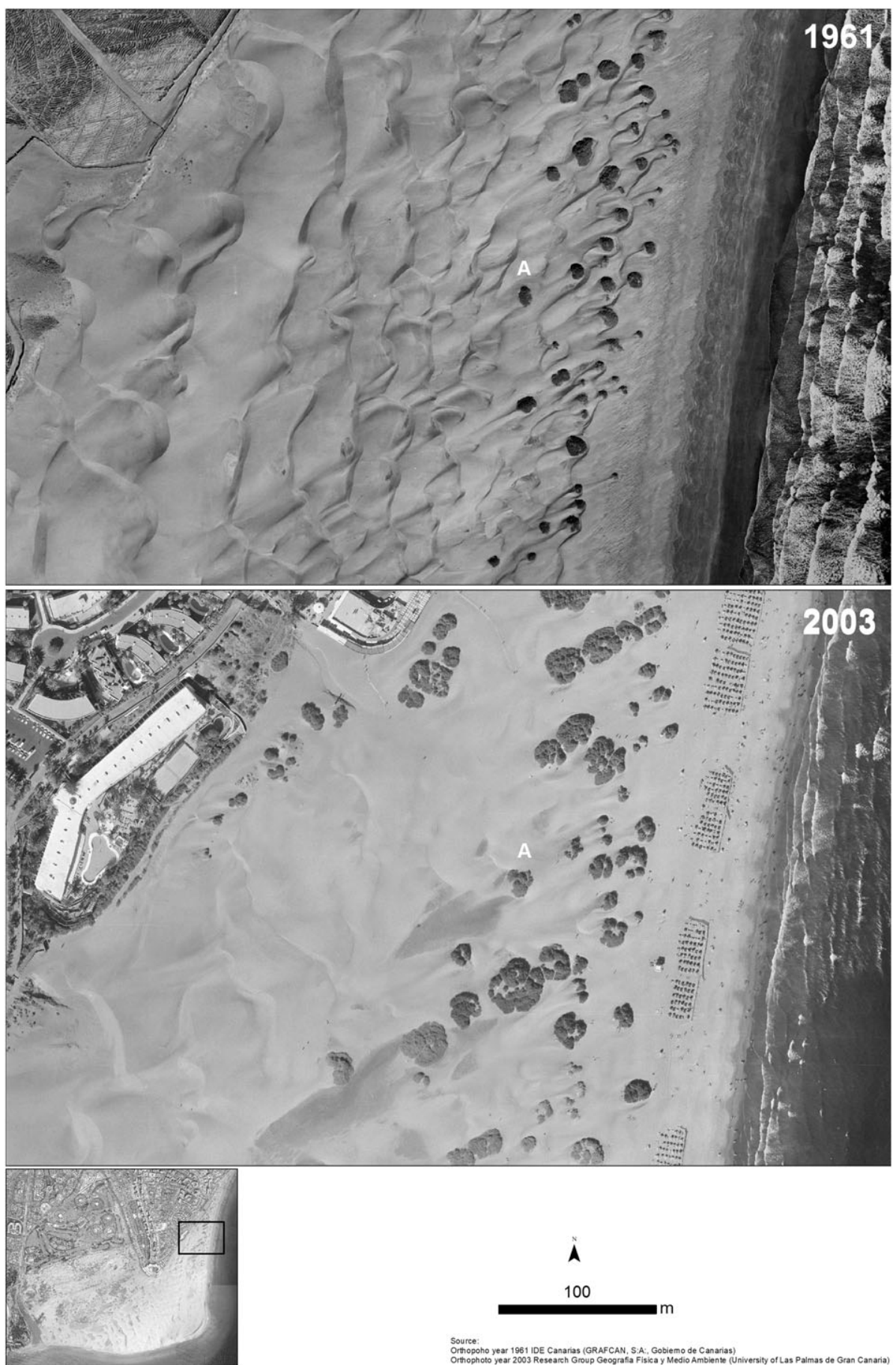

Figure 8. Example of barchanization processes: transformation of barchanoid ridges in barchan dunes and sand sheets between year 1961 (top) and year 2003 (bottom) to leeward of the shrubs that form the foredune. The letter A indicates the position of a shrub (Traganum moquinii species) to facilitate the interpretation of the orthophoto.

Durán and Herrmann, 2006; Martinho et al., 2010). This fits with the link between barchanization and the existence of a natural sedimentary deficit. Thus, the decline in the contributions of nearshore sand deposits, or other causes, has produced a re-balancing of the system, which can no longer maintain the existing barchanoid ridges that have finally become barchan dunes and sand sheets.

Destabilization occurs as a result of the disappearance of the vegetation (by natural or human reasons) or because of a change in the direction of advance of the dunes, which invaded areas occupied by vegetation. Vegetation removal in the foredune zone is partly related to the activities carried out by the beach users (Hernández-Cordero et al., 2012), but could also be due to the acceleration of aeolian flow in the southern El Inglés beach by the effect of urbanization
(Hernández-Calvento et al., 2014; Smith et al., 2017). Destabilization, as deflation, is a consequence of the removal of shrubbery, formed by Traganum moquinii, which has produced the transformation of the foredune into barchan dunes and sand sheets with its consequent fragmentation (Hernández-Cordero et al., 2012). These free dunes alternate with deflation surfaces, depending on the sand inputs. In other dune systems, changes in the vegetation of the foredune due to human pressure have generated other processes of destabilization such as the formation of blowouts (Ojeda Zújar et al., 2002).

Retrogradation and dune loss/beach gain processes result from shoreline retrogradation or recession, probably due to a natural sedimentary deficit and increasing the output rate of sediments to the sea by changes in aeolian dynamics by 


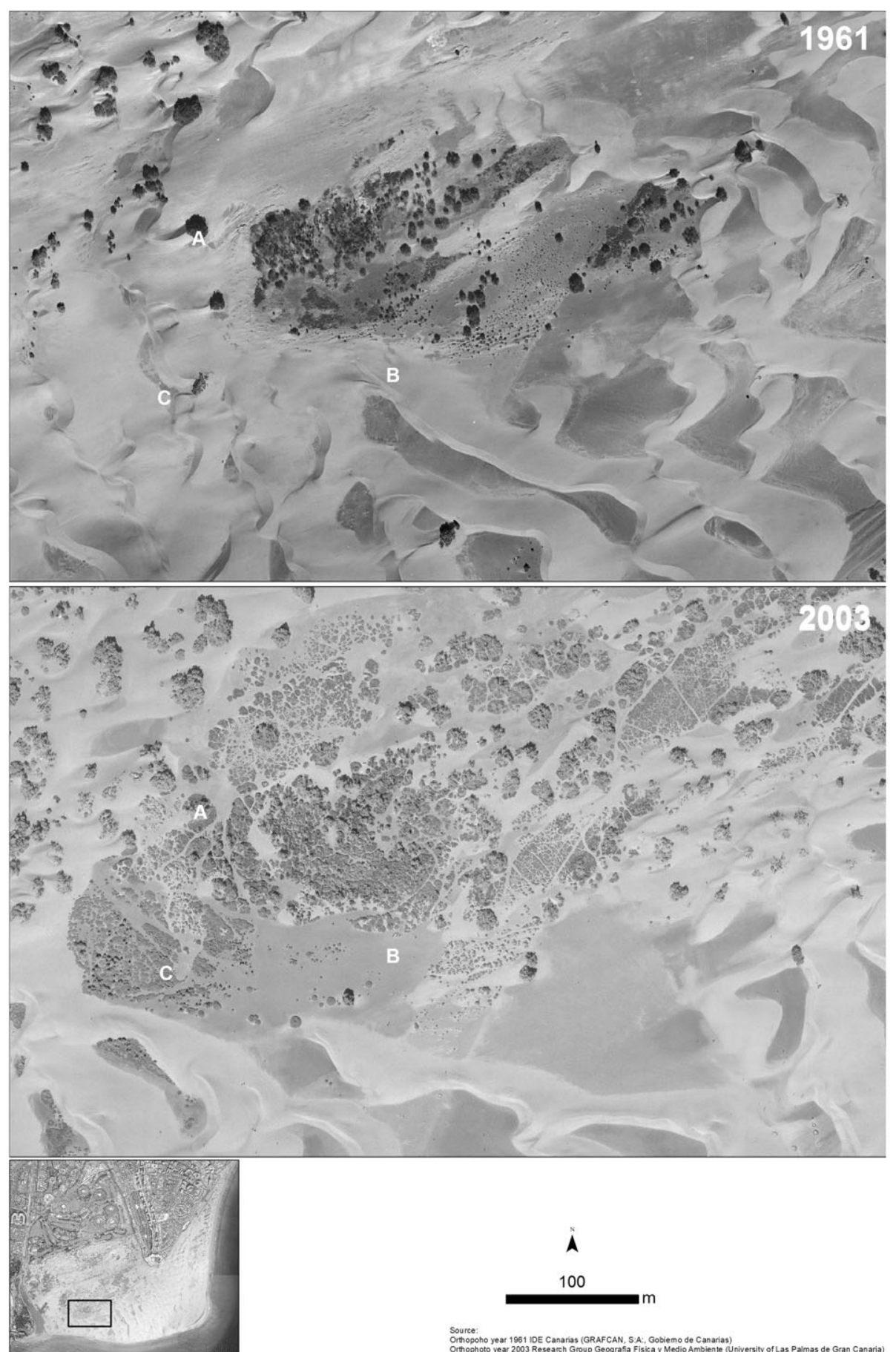

Figure 9. Example of deflation and salinization/halophytication processes: transformation of dunes in a deflation surface (B) and deflation surface colonized by halophilous vegetation (C) between year 1961 (top) and year 2003 (bottom). The letter A indicates the position of a tree (specimens of Tamarix canariensis) to facilitate the interpretation of the orthophoto.

touristic urbanizations (Hernández- Calvento et al., 2014). Coastal erosion is a common phenomenon in the dune fields around the world, both transgressive and non-transgressive, and it is generally associated with an alteration in the aeolian sedimentary and marine dynamic due to forest plantations (Piotrowska, 1989) or to construction of urbanizations and infrastructures (Alonso et al., 2002, 2006; Ojeda Zújar et al., 2002; El Banna, 2004; Balduzzi et al., 2006; El Banna and Frihy, 2009; Miccadei et al., 2011; Flor-Blanco et al., 2013). Recent studies indicate that $40 \%$ of the continental coast of Portugal is occupied by beach-dune systems that display erosive processes, being more important in areas with greater human intervention which has led to the existence of a sedimentary deficit (Lira et al., 2016). In other transgressive dune systems of the Canary Islands, as, for example, on the island of Fuerteventura, some beaches have experienced erosion due to the construction of urbanizations and roads, because they have interrupted the sediment transport from the source areas to the beaches (Alonso et al., 2002, 2006). However, in some transgressive dune systems, coastal erosion may be related to natural processes because of their high dynamism (Fernández et al., 2009; Hesp, 2013).

Finally, the flooding was due to a modification in the Fataga ravine course, resulting in an alteration of the configuration of the lagoon that forms at its mouth (Hernández-Calvento, 2006).

Similar geomorphological changes to those observed in Maspalomas also occurred in Argentina, as deflation, increased vegetation cover, a decline in the rate of dune movement, increased beach erosion and degradation of dune landforms occurred (Marcomini and Maidana, 2004). In both areas these 


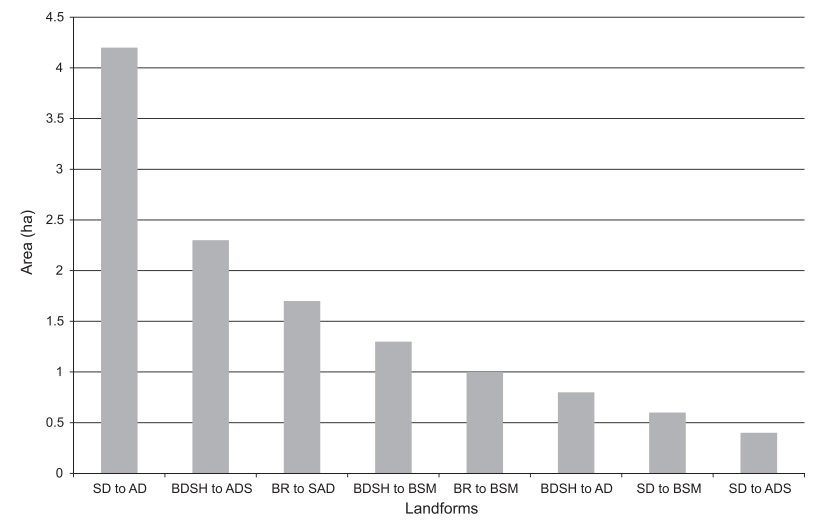

Figure 10. Area occupied by landform changes in the process of anthropization. SD: stabilized dunes; AD: anthropogeic deposits; BDSH: barchan dunes and sand sheets; ADS: anthropogenic deposits with sand; BR: barchanoid ridges; SAD: slope with anthropogenic deposits; BSM: bucket of sand mining.

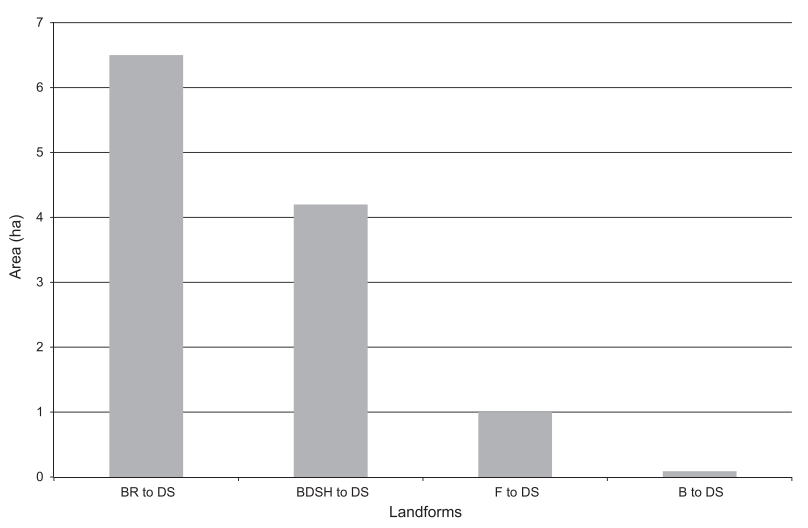

Figure 11. Area occupied by landform changes in a deflation process. BR: barchanoid ridges; DS: deflation surface; BDSH: barchan dunes and sand sheets; F: foredune; B: beach.

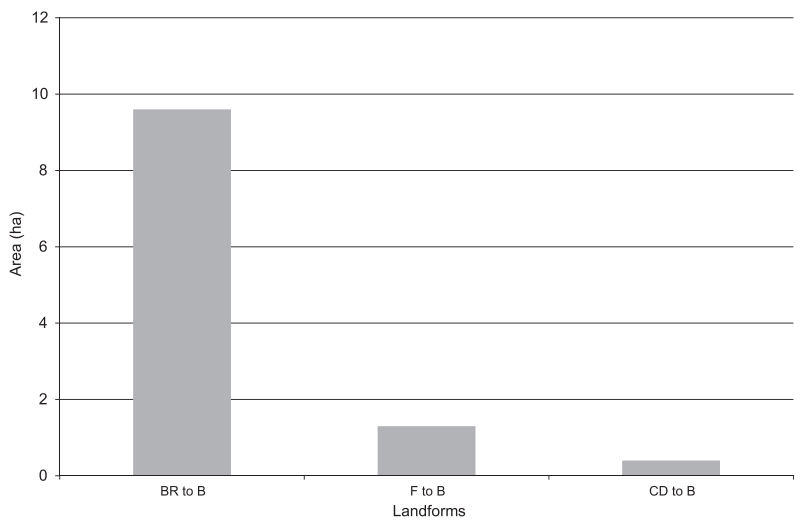

Figure 12. Area occupied by landform changes in a dune loss/beach gain process. BR: barchanoid ridges; $\mathrm{B}$ : beach; $\mathrm{F}$ : foredune; $\mathrm{CD}$ : climbing dune.

changes are due to the combination of natural and anthropogenic factors. However, in the case of Argentina, natural factors are associated with an increase in rainfall, while in Maspalomas it seems to be due to a natural sedimentary deficit. In the dune systems of Wales (UK), there has been a reduction in the areas occupied by bare sand, due to an increase in vegetation cover, a fact that is associated with changes in climate and a reduction in the sedimentary contributions (Pye et al., 2014). In some dune systems in the United States the environmental changes are

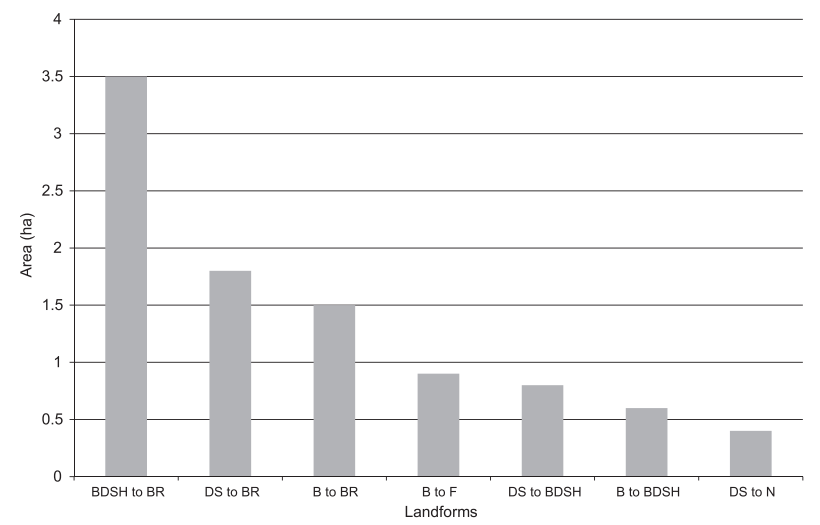

Figure 13. Area occupied by changes in landforms by the dune formation process. BDSH: barchan dunes and sand sheets; BR: barchanoid ridges; DS: deflation surface; $\mathrm{B}$ : beach; F: foredune; $\mathrm{N}$ : nebkhas.

associated with changes in land cover: first by a rapid growth of the dunes by the removal of the vegetation due to excessive logging; second the increase in deflation by the reduction in sand supply due to the increase in vegetation cover by anthropogenic causes and urban development (Mitasova et al., 2005).

Vegetation is usually used as an indicator (bioindicators) of natural processes and environmental changes in dune systems (García-Mora et al., 1999; Tzatzanis et al., 2003; Grunewald and Schubert, 2007; Levin et al., 2007; Lomba et al., 2008). However, in mobile dunes of transgressive dune systems, especially in the arid ones, vegetation can be scarce, so bioindicators may be less useful. In this context, the use of changes in landforms (geoindicator) by identifying the operative geomorphological processes can be effective tool to analyze the environmental changes induced by human activities or changes related to natural dynamics.

\section{Conclusions}

The geomorphological transformation of $66.4 \%$ of the Maspalomas dune field surface in four decades indicates that environmental changes can occur rapidly in such arid dunefields. Therefore, it is necessary to use procedures and tools to detect those changes, and bioindicators are often used to study these environmental changes. However, in ecosystems where vegetation is scarce, such as in arid transgressive dune fields, the sole use of bioindicators may not be the most effective tool. The geomorphological processes identified in this study allowed us to synthesize the spatio-temporal changes observed in the landforms across the dunefield, and then subsequently use these as indicators of environmental changes (geoindicators).

Geomorphological analysis of the Maspalomas dune field allowed us to identify geomorphological processes which could then be associated with specific causes of change. Therefore, this study area has been used as a pilot area to determine which gemorphological changes linked to human and natural causes, occur in the arid transgressive dune system and to investigate the origin of these changes, so that the use of geoindicators as utilized here might be applied to other dune fields.

In this study, the different groups of processes identified indicate specific environmental changes. Thus, the processes of stabilization, barchanization, salinization/halophytication, deflation, dune loss/beach gain/progradation and retrogradation are indicators of the existence of alterations in the aeolian sedimentary dynamics, due to natural or human causes. The 
processes of dune formation and progradation are associated with the natural dynamics of the displacement or transgression of dunes and changes in coastal processes that indicate a redistribution of sediments. The process of destabilization is associated with the destruction of vegetation, which generates the formation of free dunes. Finally, the processes of anthropization by urban occupation and anthropization are the direct result of human activities.

Each one of the processes associated with certain environmental changes allows us to interpret the specific causes of them. For example, within the group of geomorphological processes that indicate an alteration of the aeolian sedimentary dynamics, there are different causes. When erosion processes occur (deflation or salinization/halophytication) the changes are associated with an acceleration of aeolian transport, in this case due to the construction of tourist urbanizations, together with the absence of a replacement of the sand mobilized by the wind. The dune loss/beach gain/progradation and retrogradation processes are the result of marine erosion along with the inability of the beach-dune system to restore the lost sand. However, the process of stabilization is associated with a decrease or blockage of aeolian sedimentary transport, due in this case to the tourist urbanizations, that generates an increase in plant colonization. When there is a simplification of the dune landforms (barchanization) everything points to a natural sedimentary deficit, since the system does not have enough sand to maintain the original dunefield characteristics.

Therefore, these identified geomorphological processes allow us to diagnose what changes have occurred and where and why they have occurred, improving the understanding of environmental alterations of this arid transgressive dune field, and allowing us to link those changes to either natural or human causes, or both.

Acknowledgements - This is a contribution to REN2003-05947, SEJ2007-64959, CSO2010-18150, CSO2013-43256-R and CSO201679673-R projects of the Spanish National Plan for R+D+i (innovation), co-financed with ERDF funds.

\section{References}

Alonso I, Alcántara-Carrió J, Cabrera L. 2002. Tourist resorts and their impact on beach erosion at Sotavento beaches, Fuerteventura, Spain. Journal of Coastal Research 36(special issue): 1-7.

Alonso I, Sánchez I, Cabrera L, Benavides A, Alcántara-Carrió J, Usera J. 2006. Decadal evolution of a coastal dune field and adjacent beaches at north of Fuerteventura (Canary Islands, Spain). Journal of Coastal Research 39(special issue): 198-203.

Atamov V, Aktoklu E, Cetin E, Aslan M, Yavuz M. 2006. Halophytication in Harran (Şanliurfa) and Amik Plain (Hatay) in Turkey. Phytologia Balcanica 12(3): 401-412.

Aufrère L. 1931. Le cycle morphologique des dunes. Annales de Géographie 40(226): 362-385.

Balduzzi I, Bozzano A, Corradi N, Mariotti LM, Vagge I. 2006. The evolution of the dune fields of Platamona-Marritza (northern Sardinia): application of remote-sensing methods. Chemistry and Ecology 22(1): 371-381.

Cabrera-Vega LL, Cruz-Avero N, Hernández-Calvento L, HernándezCordero Al, Fernández-Cabrera E. 2013. Morphological changes in dunes as an indicator of anthropogenic interferences in arid dune fields. Journal of Coastal Research 65(special issue): 1271-1276.

Carretero S, Braga F, Kruse E, Tosi L. 2014. Temporal analysis of the changes in the sand-dune barrier in the Buenos Aires Province, Argentina, and their relationship with the water resources. Applied Geography 54: 169-181.

Durán O, Herrmann HJ. 2006. Vegetation against dune mobility. Physical Review Letters 97: 188001.

El Banna MM. 2004. Nature and human impact on Nile Delta coastal sand dunes, Egypt. Environmental Geology 45: 690-695.
El Banna MM, Frihy OE. 2009. Human-induced changes in the geomorphology of the northeastern coast of the Nile delta, Egypt. Geomophology 107: 72-78.

Fernández GB, Pereira TG, da Rocha TB. 2009. Coastal dunes along Rio de Janeiro coast: evolution and management. Journal of Coastal Research 56(special issue): 307-311.

Flor-Blanco G, Flor G, Pando L. 2013. Evolution of the Salinas-El Espartal and Xagó beach/dune systems in north-western Spain over recent decades: evidence for responses to natural processes and anthropogenic interventions. Geo-Marine Letters 33: 143-157.

García-Mora MR, Gallego-Fernández JB, García-Novo F. 1999. Plant functional types in coastal foredunes in relation to environmental stress and disturbance. Journal of Vegetation Science 10(1): 27-34.

García-Romero L, Hernández-Cordero Al, Fernández-Cabrera E, PeñaAlonso C, Hernández-Calvento L, Pérez-Chacón E. 2016. Urbantouristic impacts on the aeolian sedimentary systems of the Canary Islands: conflict between development and conservation. Island Studies Journal 11(1): 91-112.

Granados Corona M, Martin Vicente A, Garcia Novo F. 1988. Longterm vegetation changes on the stabilized dunes of Doñana National Park (SW Spain). Vegetatio 75: 73-80.

Grunewald R, Schubert H. 2007. The definition of a new plant diversity index ' $\mathrm{H}$ ' dune' for assessing human damage on coastal dunesderived from the Shannon index of entropy $\mathrm{H}^{\prime}$. Ecological Indicators 7: 1-21.

Hernández L, Alonso I, Sánchez-Pérez I, Alcántara-Carrió J, Montesdeoca I. 2007. Shortage of sediments in the Maspalomas dune field (Gran Canaria, Canary Islands) deduced from analysis of aerial photographs, foraminiferal content, and sediment transport trends. Journal of Coastal Research 23: 993-999.

Hernández-Calvento L. 2006. Diagnóstico sobre la Evolución del Sistema de Dunas de Maspalomas (1960-2000) [Diagnosis of Evolution Dunefield of Maspalomas (1960-2000)]. Las Palmas de Gran Canaria: Cabildo de Gran Canaria.

Hernández-Calvento L, Jackson DWT, Medina R, Hernández-Cordero Al, Cruz N, Requejo S. 2014. Downwind effects on an arid dunefield from an evolving urbanised area. Aeolian Research 15: 301-309.

Hernández-Cordero Al, Pérez-Chacón Espino E, Hernández-Calvento L. 2006. Vegetation colonisation processes related to a reduction in sediment supply to the coastal dune field of Maspalomas (Gran Canaria, Canary Islands, Spain). Journal of Coastal Research 48(special issue): $69-76$.

Hernández-Cordero AI, Pérez-Chacón E, Hernández-Calvento L. 2012. La investigación como soporte de la gestión: el ejemplo de la duna costera (foredune) de Maspalomas (Gran Canaria, Islas Canarias) [Research as support of management: the example of the foredune of Maspalomas (Gran Canaria, Canary Islands)]. In La gestión integrada de playas y dunas: experiencias en Latinoamérica y Europa, Rodríguez-Perea A, Pons GX, Roig-Munar FX, Martín-Prieto JA, MirGual M, Cabrera JA (eds), Monografies de la Societat d'Història Natural de les Balears, 19. Societat d'Història Natural de les Balears: Palma de Mallorca.

Hernández-Cordero Al, Hernández-Calvento L, Pérez-Chacón Espino E. 2015. Relationship between vegetation dynamics and dune mobility in an arid transgressive coastal system, Maspalomas, Canary Islands. Geomorphology 238: 160-176.

Hesp PA. 1991. Ecological processes and plant adaptations on coastal dunes. Journal of Arid Environments 21: 165-191.

Hesp PA. 2001. The Manawatu dunefield: environmental change and human impacts. New Zealand Geographer 57(2): 33-40.

Hesp PA. 2013. Conceptual models of the evolution of transgressive dune field systems. Geomorphology 199: 138-149.

Hesp PA, Walker IJ. 2013. Coastal Dunes. In Aeolian Geomorphology. Treatise on Geomorphology, Shroder JF, Landcaster N, Shermann DJ, Baas ACW (eds), Vol. 11. Academic Press: San Diego, CA; 328-355.

Jackson NL, Nordstrom KF. 2011. Aeolian sediment transport and landforms in managed coastal systems: a review. Aeolian Research 3: 181-196.

Jackson D, Cruz-Avero N, Smyth T, Hernández-Calvento L. 2013. 3D airflow modelling and dune migration patterns in an arid coastal dune field. Journal of Coastal Research 65(special issue): 1301-1306. 
Kiss T, Sipos G, Kovács F. 2009. Human impact on fixed sand dunes revealed by morphometric analysis. Earth Surface Processes and Landforms 34: 700-711.

Kutiel P, Cohen O, Shoshany M, Shub M. 2004. Vegetation establishment on the southern Israeli coastal sand dunes between the years 1965 and 1999. Landscape and Urban Planning 67: 141-156.

Levin N, Ben-Dor E. 2004. Monitoring sand dune stabilization along the coastal dunes of Ashdod-Nizanim, Israel, 1945-1999. Journal of Arid Environments 58: 335-355.

Levin N, Kidron GJ, Ben-Dor E. 2007. A field quantification of coastal dune perennial plants as indicators of surface stability, erosion or deposition. Sedimentology 55(4): 751-772.

Levin N. 2011. Climate-driven changes in tropical cyclone intensity shape dune activity on Earth's largest sand island. Geomorphology 125: 239-252.

Lira C, Silva A, Taborda R, Andrade C. 2016. Coastline evolution of Portuguese low-lying sandy coast in the last 50 years: an integrated approach. Earth System Science Data 8(1): 265-278.

Lomba A, Alves P, Honrado J. 2008. Endemic sand dune vegetation of the northwest Iberian Peninsula: diversity, dynamics, and significance for bioindication and monitoring of coastal landscapes. Journal of Coastal Research 24(2B): 113-121.

Marcomini SC, Maidana N. 2004. Response of eolian ecosystems to minor climatic changes. Journal of Coastal Research 39(special issue): 204-208.

Martinho CT, Hesp PA, Dillenburg SR. 2010. Morphological and temporal variations of transgressive dunefields of the northern and mid-littoral Rio Grande do Sul coast, Southern Brazil. Geomorphology 117: 14-32.

Máyer Suárez P, Pérez-Chacón Espino E, Cruz Avero N, HernándezCalvento L. 2012. Características del viento en el campo de dunas de Maspalomas (Gran Canaria, Islas Canarias, España). Nimbus 29-30: 381-397.

Miccadei E, Mascioli F, Piacentini T, Ricci F. 2011. Geomorphological features of coastal dunes along the Central Adriatic Coast (Abruzzo, Italy). Journal of Coastal Research 27(6): 1122-1136.

Miot da Silva G, Martinho CT, Hesp P, Keim BD, Ferligoj Y. 2013. Changes in dunefield geomorphology and vegetation cover as a response to local and regional climate variations. Journal of Coastal Research 65(special issue): 1307-1312.

Miot da Silva G, Hesp PA. 2013. Increasing rainfall, decreasing winds, and historical changes in Santa Catarina dunefields, southern Brazil. Earth Surface Processes and Landforms 38: 1036-1045.

Mitasova H, Overton M, Harmon RS. 2005. Geospatial analysis of a coastal sand dune field evolution: Jockey's Ridge, North Carolina. Geomorphology 72: 204-221.
Ojeda Zújar J, Borgniet L, Pérez Romero AM, Loder JF. 2002. Monitoring morphological changes along the coast of Huelva (SW Spain) using soft-copy photogrammetry and GIS. Journal of Coastal Conservation 8: 69-76.

Ojeda J, Vallejo I, Hernández L, Álvarez J. 2007. Fotogrametría digital y lidar como fuentes de información en geomorfológica litoral (marismas mareales y sistemas dunares): el potencial de su análisis espacial a través de SIG. Boletín de la A.G.E. 44: 215-233.

Piotrowska H. 1989. Natural and anthropogenic changes in sanddunes and their vegetation on the southern Baltic coast. In Perspectives in Coastal Dune Management, van der Meulen F, Jungerius PD, Visser JH (eds). SPB Academic Publishing: The Hague; 33-40.

Pye K, Blott SJ, Howe MA. 2014. Coastal dune stabilization in Wales and requirements for rejuvenation. Journal of Coastal Conservation 18: $27-54$.

Rust IC, Illenberger WK. 1996. Coastal dunes: sensitive or not? Landscape and Urban Planning 34: 165-169.

Smith AB, Jackson DWT, Cooper JAG, Hernández-Calvento L. 2017. Quantifying the role of urbanization on airflow perturbations and dunefield evolution. Earth's Future 5(5): 520-539. https://doi.org/ 10.1002/2016EF000524.

Tsoar H. 2001. Types of aeolian sand dunes and their formation. In Geomorphological Fluid Mechanics, Balmforth NJ, Provenzale A (eds). Springer: Berlin; 403-429.

Tsoar H. 2005. Sand dunes mobility and stability in relation to climate. Physica A 357: 50-56.

Tsoar H, Blumberg DG. 2002. Formation of parabolic dunes from barchan and transverse dunes along Israel's Mediterranean coast. Earth Surface Processes and Landforms 27: 1147-1161.

Tsoar H, Levin N, Porat N, Maia LP, Herrmann HJ, Tatumi SH, Claudino-Sales V. 2009. The effect of climate change on the mobility and stability of coastal sand dunes in Ceará State (NE Brazil). Quaternary Research 71: 217-226.

Tzatzanis M, Wrbka T, Sauberer N. 2003. Landscape and vegetation responses to human impact in sandy coasts of Western Crete, Greece. Journal for Nature Conservation 11: 187-195.

Yizhaq H, Ashkenazy Y, Tsoar H. 2007. Why do active and stabilized dunes coexist under the same climatic conditions? Physical Review Letters 98: 188001 .

Yizhaq H, Ashkenazy Y, Tsoar H. 2009. Sand dune dynamics and climate change: a modeling approach. Journal of Geophysical Research 114: F01023. https://doi.org/10.1029/2008JF001138.

Yizhaq H, Ashkenazya Y, Levin N, Tsoar H. 2013. Spatiotemporal model for the progression of transgressive dunes. Physica A 392: 4502-4515. 